are at work for cellular antigens also. This confirms their importance in possible manipulations of anti-tumor immune response $[36,37]$.

I am grateful to Dr. G. Della Porta for helpful discussion during the course of these studies. The skillful technical assistance of Ms. Liliane Parmi and Mr. Carlo Brunati is acknowledged.

Received September 20, 1974; in final revised form January 18, 1975.

\section{References}

1 Schierman, L.W. and McBride, R.A., Science 1967. 156: 658.

2 Stimpfling, J.H. and McBroom, C.R., Transplantation 1971. 11: 87.

3 Watkins, J.F. and Chen, L., Nature 1969. 223: 1018.

4 Britton, S., Transplant. Rev. 1971. 7: 146.

5 Colnaghi, M.I. and Della Porta, G., J. Nat. Cancer Inst. 1973. 50: 173.

6 Di Marco, A.T., Franceschi, C. and Prodi, G., Eur. J. Immunol. 1972. 2: 240 .

7 Boyse, E.A., Bressler, E., Iridani, C.A. and Lardis, M., Transplantatior. 1970. 9: 339.

8 Greaves, M.F. and Raff, M.C., Nature-New Biol. 1971. 233: 239.

9 Iverson, G.M. and Lindenmann, J., Eur. J. Immunol. 1972. 2: 195.

10 Czajkowski, N.P., Rosenblatt, M., Wolf, P.L. and Vazquez, J., Lancet 1967. ii: 905.

11 Braun, W., Plescia, O.J., Raskova, J. and Webb, D., Isr. J. Med. 1971. 7: 72.

12 Kurth, R. and Bauer, H., Eur. J. Immunol. 1973. 3: 95.

13 Lindenmann, J. and Klein, P.A., J. Exp. Med. 1967. 126: 93.

14 Kobayashi, H., Sendo, F., Kaji, H., Shirai, T., Saito, H., Takeichi, N., Hosokawa, M. and Kodama, T., J. Nat. Cancer Inst. 1970. 44: 11.

15 Boone, C., Blackman, K. and Brandchaft, P., Nature 1971. 231 : 265.
16 Beverley, P.C.L., Lowenthal, R.M. and Tyrrell, D.A.J., Int. $J$. Cancer 1973. 11: 212.

17 Martin, W.J., Wunderlich, J.R., Fletcher, F. and Inman, J.K., Proc. Nat. Acad. Sci. US 1971. 68: 469.

18 Mitchison, N.A., Transplant. Proc. 1970. 2: 92.

19 McBride, R.A. and Schierman, L.W., J. Immunol. 1973. 110: 1710.

20 Boone, C.W., Paranjpe, M., Orme, T. and Gillette, R., Int. J. Cancer 1974. 13: 543.

21 McCullagh, P.J., J. Exp. Med. 1970. 132: 916.

22 Katz, D.H., Paul, W.E., Goidl, E.A. and Benacerraf, B. J. Exp. Med. 1971. 133: 169.

23 Kreth, H.W. and Williamson, A.R., Nature 1971. 234 : 454.

24 Mitchison, N.A., Eur. J. Immunol. 1971. 1: 18.

25 Bretscher, P.A. and Cohn, M., Nature 1968. 220: 444.

26 Fujimoto, S., Chen, C.H., Sabbadini, E. and Sehon, A.H., J. Immunol. 1973. 111: 1093.

27 Uhr, J.W. and Möller, G., Advan. Immunol. 1968. 8: 81.

28 Wigzell, H., J. Exp. Med. 1966. $124: 953$.

29 Rowley, D.A. and Fitch, F.W., J. Exp. Med. 1964. 120: 987.

30 Möller, G., Andersson, J. and Sjöberg, O., Cell. Immunol. 1972. 4: 416.

31 Schmidtke, J.R. and Dixon, F.J., J. Exp. Med. 1972. 136: 392.

32 Louis, J.A., Chiller, J.M. and Weigle, W.O., J. Expr. Med. 1973. 138: 1481 .

33 Schrader, J.W., Eur. J. Immunol. 1974. 4: 20.

34 Katz, D.H., Paul, W.E. and Benacerraf, B., J. Immunol. 1971. 107: 1319.

35 Devlin, R.G., McCurdy, J.D. and Baronowsky, P.E., J. Exp. Med. 1974. 139: 230.

36 Katz, D.H., Ellman, L., Paul, W.E., Green, I. and Benacerraf, B., Cancer Res. 1972. 32: 133.

37 Ellman, L., Katz, D.H., Green, I., Paul, W.E. and Benacerraf, B., Cancer Res. 1972. 32: 141.

\section{U. Koszinowski and R. Thomssen}

Institut für Hygiene und Medizinische Mikrobiologie der Universität Göttingen

\title{
Target cell-dependent $T$ cell-mediated lysis of vaccinia virus-infected cells
}

Vaccinia virus specific cytotoxicity against infected target cells was observed in vitro. Spleen lymphocytes from normal and immunized mice of the inbred strains $\mathrm{C} 3 \mathrm{H}$ and $\mathrm{DBA} / 2$ were incubated with vaccinia virus-infected and noninfected ${ }^{51}$ Cr-labeled mastocytoma P-81 5-X2 cells and L-929 fibroblasts, which were used as targets. Cytotoxic lymphocytes could be isolated from the mice as early as 2 days after infection with vaccinia virus. The highest cytotoxic effect was obtained with lymphocytes taken 6 days after infection. The degree of lysis was correlated with the ratio of immune lymphocytes to target cells. Specific blocking of target cell lysis resulted after addition of anti-vaccinia antibody from different sources. The effector cells could be characterized as $T$ cells by elimination of macrophages and B cells. Target cell killing was only possible in a syngeneic system; allogeneic infected target cells were not lysed significantly.

[1 974]

Correspondence: Ulrich Koszinowski, Institut für Hygiene und Medizinische Mikrobiologie der Universität Göttingen, D-34 Göttingen, Kreuzbergring 57, Fed. Rep. Germany

Abbreviations: B cell: Antibody-forming cell precursor CL: Cy totoxic lymphocytes CMI: Cell-mediated immunity FCS: Fetal calf serum LPS: Lipopolysaccharide MEM: Eagle's minimum essential medium PWM: Pokeweed mitogen PHA: Phytohemagglutinin T cell: Thymusderived cell TCID: Tissue culture infective dosis

\section{Introduction}

Cell-mediated immune mechanisms play an essential role in resistance to viral infections [1-4]. Lymphocyte transformation and migration inhibition tests have been adopted to evaluate the interactions between virus and lymphocytes. To prove cell-mediated immunity, the effect of $T$ cells has to be demonstrated making it necessary to specify transformation tests with respect to the action of $B$ and $T$ cells. Furthermore, these tests give no evidence about the specific action of $T$ cells 
on virus particles or virus-infected cells. Interactions between immune lymphocytes and virus-infected cells have been demonstrated in vitro using different viruses [5-15]. In this study we established an in vitro system to show cytotoxic actions of spleen cells from vaccinia virus-infected mice against vaccinia-infected target cells. We investigated: (a) the kinetics of in vivo production of cytotoxic lymphocytes (CL), (b) the cell type of the effector cell, (c) the interactions between antibodies and $C L,(d)$ the virus specificity and the target cell specificity of the in vitro reaction.

\section{Materials and methods}

\subsection{Viruses and animals used}

Vaccinia virus strain WR was propagated in Vero cells (Green African monkey kidney) cultivated in Eagle's medium supplemented with $100 \mathrm{IU} / \mathrm{ml}$ penicillin, $100 \mu \mathrm{g} / \mathrm{ml}$ streptomycin and $10 \%$ inactivated calf serum. Stock virus contained $10^{6} \mathrm{TCID}_{50} /$ $\mathrm{ml}$. Herpes simplex virus type I was grown in Vero cells; the stock virus was equilibrated to $10^{6} \mathrm{TCID}_{50} / \mathrm{ml}$. Titration of virus was performed in Vero cells using the microtiter system (Greiner, Nürtingen, No 220 ART) with eight wells for every logarithmic dilution step. Reading was performed according to the method of Reed and Muench. Mice of the inbred strains C 3 H/TIF and DBA/2 (purchased from G.L. Bomholtgård, Ry Denmark) were used throughout the study.

\subsection{Lymphoid cell suspensions}

Lymphocytes were obtained from the mouse spleens at different times after injection of $1-2 \mathrm{ml} 10^{5}-10^{6} \mathrm{TCID}_{50} / \mathrm{ml}$ of vaccinia virus, herpes simplex virus or Eagle's medium. Cell suspensions from spleens were obtained by the following procedure: spleens from five mice were aseptically removed, homogenized by hand with one gentle stroke in a $15 \mathrm{ml}$ glass homogenizer (Tenbroeck) containing $10 \mathrm{ml}$ Eagle's medium supplemented with $10 \%$ fetal calf serum, $1 \%$ L-glutamin (200 mmoles), $1 \%$ 50-fold concentrated amino acids (Microbiological Assoc., Bethesda, Md., No 13-606), $100 \mathrm{IU} / \mathrm{ml}$ penicillin and $100 \mu \mathrm{g} / \mathrm{ml}$ streptomycin. The suspension was transferred to a tube, underlayed with calf serum and incubated for 5 min at $4{ }^{\circ} \mathrm{C}$ to remove spleen debris and clumped cells. The supernatant was removed and underlayed again with serum and the cells were pelleted by centrifugation for $10 \mathrm{~min}$ with $250 \mathrm{xg}$ at $4{ }^{\circ} \mathrm{C}$. The supernatant containing smooth debris was discarded. The cells were resuspended and viability was tested by trypan blue exclusion. Depletion of erythrocytes was performed by Ficoll-Isopaque discontinous gradient centrifugation according to the method of Boyum [16]. Adherent cells were removed by passing the spleen cells through a column of siliconed glass beads according to the method of Shortman et al. [17]. The efferent cell population was free of macrophages as was confirmed by Giemsa staining.

\subsection{B cell elimination}

Immunoglobulin-bearing cells were separated by adherent properties. Spleen cell suspensions were first incubated in nylon wool columns for $45 \mathrm{~min}$ at $37^{\circ} \mathrm{C}$ and then washed slowly with warm medium according to the method of Julius et al. [18]. The decrease of the percentage of Ig-bearing cells was controlled by direct immunofluorescence staining with fluorescein isothiocyanate-conjugated rabbit anti-mouse Ig (Microbiological Assoc., No 51-792). The amount of labeled cells of the effluent cell fraction was $1 \%$, while the unfractionated cell suspensions contained 45-50\% Ig-bearing cells.
Elimination of B cells was also tested by the capability of lymphocytes to respond to mitogens [19]. The response to phytohemagglutinin (PHA) (Wellcome, Buckingham, Kent) pokeweed mitogen (PWM) (Grand Island Biol. Co., Grand Island, N.Y. Cat. No 536) and lipopolysaccharide W (LPS) (Difco, Detroit, Mich., Cat. No 3122-25) was studied by $\left[{ }^{3} \mathrm{H}\right]$ thymidine incorporation. While there were no significant alterations of PHA transformation ratios, a significant reduction of transformation by PWM and LPA was obtained in the B cell-depleted cell fraction.

Elimination of B cells was performed by incubation with goat antiserum to mouse Ig (Gibco, BCL 1039). The serum was absorbed with $\mathrm{C} 3 \mathrm{H}$ mouse thymocytes until there was no more cytotoxicity against thymocytes. $15 \times 10^{6}$ cells were incubated in $0.2 \mathrm{ml}$ of antiserum $30 \mathrm{~min}$ in $37^{\circ} \mathrm{C}$, washed and incubated again with an equal volume of guinea pig complement absorbed with mouse liver powder.

\section{4. $T$ cell elimination}

Anti- $\Theta$ serum from AKR mice was kindly provided by Dr. Röllinghoff, Mainz. $15 \times 10^{6}$ spleen cells were incubated in $0.2 \mathrm{ml}$ anti- $\Theta$ serum for $30 \mathrm{~min}$ at $37^{\circ} \mathrm{C}$. Controls were run with normal mouse serum. The cells were washed and resuspended in $0.2 \mathrm{ml}$ guinea pig complement absorbed with mouse liver powder and agarose [20]. After incubation for $30 \mathrm{~min}$ at $37^{\circ} \mathrm{C}$ the cells were washed and resuspended to the desired concentration. The viability of the cells was tested by the trypan blue exclusion test.

\subsection{Anti-vaccinia serum}

Hyperimmune serum was obtained from sensitized rabbits injected intracutaneously with $5 \mathrm{ml} 10^{6} \mathrm{TCID}_{50} / \mathrm{ml}$ followed 6-10 weeks later by booster intravenous injections of the same dosage. Syngeneic hyperimmune serum was obtained from mice after three intraperitoneal injections of $2 \mathrm{ml} 10^{6}$ $\mathrm{TCID}_{50} / \mathrm{ml}$ given at two week intervals. The animals were bled one week after the last injection. Normal serum was obtained from noninfected animals. All sera were inactivated and stored at $-70^{\circ} \mathrm{C}$.

\subsection{Target cells}

L-929 cells, kindly provided by Dr. Lehmann-Grube, Hamburg, were grown as monolayers in MEM containing $10 \%$ FCS and $100 \mu \mathrm{g} / \mathrm{ml}$ of penicillin and streptomycin in Roux bottles. Mastocytoma P-815-X2 suspension cultures were grown in $10 \mathrm{~cm}$ Petri dishes containing Dulbecco's fortified Eagle's medium (Grand Island Biological Co.) with $10 \%$ FCS and antibiotics, on a rocker platform (Bellco Glass Co, Vineland, N.Y.) in a humidified $8 \% \mathrm{CO}_{2}$-atmosphere.

\subsection{Infection of target cells}

Monolayers of L-929 cells were trypsinized, suspended in fresh medium and plated in $0.1 \mathrm{ml}$ volumes in sterile flat bottom microtest plates (Greiner, Nürtingen No 220 ART) to reach a final concentration of $5 \times 10^{4}$ cells/well. Five hours later the medium was removed and the cells were incubated with $0.2 \mathrm{ml}$ virus suspension containing $5 \times 10^{5} \mathrm{TCID}_{50} /$ $0.2 \mathrm{ml}$ medium. Two hours later all the supernatants were discarded and fresh medium was added. Suspensions of mastocytoma P-815-X2 cells were infected by incubating the cells in a medium containing $10 \mathrm{TCID}_{50}$ of virus per mastocytoma cell under constant rocking. After $2 \mathrm{~h}$ the cells were washed and resuspended in fresh medium. 
Five times $10^{6}$ infected or noninfected mastocytoma cells were suspended in $0.2 \mathrm{ml}$ medium and $100 \mu \mathrm{Ci}{ }^{51} \mathrm{Cr}$ (sodiumchromat, Amersham, Buchler, Braunschweig No CJS1P, spec. activity $100-200 \mathrm{mCi} / \mathrm{mg} \mathrm{Cr}$ ) was added. After $2 \mathrm{~h}$ incubation the cells were washed three times, resuspended to the required concentration and dispensed in microtiter wells to a final concentration of $5 \times 10^{4}$ cells/well. Infected or noninfected L-929 monolayers were labeled by adding $1 \mu \mathrm{Ci}^{51} \mathrm{Cr}$ to each well. After $2 \mathrm{~h}$ incubation the monolayers were gently washed three times.

\subsection{Cytotoxic assay}

The assay is a modification of the technique described by Brunner et al. [21]. Lymphocytes and target cells were incubated in sterile flat bottom microtiter plates with a volume of $0.25 \mathrm{ml}$ per well at $37{ }^{\circ} \mathrm{C}$ in an atmosphere of $8 \% \mathrm{CO}_{2}$ and $92 \%$ air. Lymphocytes from infected and control mice were added to the ${ }^{51} \mathrm{Cr}$-labeled normal or infected target cells usually reaching a final ratio of 100 spleen cells to 1 target cell in a volume of $0.2 \mathrm{ml}$. Routinely, $5 \times 10^{6}$ spleen cells were added to $5 \times 10^{4}$ target cells. If the number of immune spleen cells was less than $5 \times 10^{6}$, the requisite number of cells from noninfected animals was added to give the required count of $5 \times 10^{6}$ lymphocytes.

Following incubation for $4-20 \mathrm{~h}$ the microplates were centrifuged at $1000 \mathrm{rpm}$ for $5 \mathrm{~min} .0 .1 \mathrm{ml}$ of cell-free supernatant was gently removed and the residual $0.1 \mathrm{ml}$ volume was harvested by vigorous pipetting to suspend the adherent cells. The volumes containing cell-free supernatant or supernatant with cells were counted and ${ }^{51} \mathrm{Cr}$ release in the whole supernatant was calculated using the formula:

\section{counts in supernatants - background counts}

Release $=\frac{}{\text { counts in whole supernatant }+ \text { cells }- \text { background counts }} \times 100$

The percentage of specific cytolysis of infected target cells was calculated by subtracting from the percentage ${ }^{51} \mathrm{Cr}$ released in the presence of immune spleen cells that percentage of ${ }^{51} \mathrm{Cr}$ released by the same number of cells from noninfected animals.

\section{Results}

\subsection{Infection conditions}

The infection of mastocy toma and L-929 cells with 10 TCID $_{50} /$ cell vaccinia virus induces cytolysis. In the $L$ cells, which were grown as monolayers, the infection led to the appearance of round cells after $4 \mathrm{~h}$, followed by aggregation of cells after $9-10 \mathrm{~h}$ and later on, to reduced adherence of the infected cells to the surface. Loss of the ${ }^{51} \mathrm{Cr}$ label was modest and generally did not exceed $5-25 \%$ after $30 \mathrm{~h}$, while noninfected L-929 cells showed spontaneous release between $10-20 \%$ (Table 1 ). A significant increase of infectivity titer was observed after $30 \mathrm{~h}$. The mastocytoma P-815-X2 suspension cultures had a similar spontaneous ${ }^{51} \mathrm{Cr}$ release after infection (Table 5). The infected cells could be used $2 \mathrm{~h}$ after infection, but often higher percentage of specific cell cytolysis by immune ly mphocytes could be obtained with cells infected for a longer period. Twelve hour infected cells were usually utilized as targets.

The development of early virus-specific antigens after vaccinia virus infection has already been described [22]. We could observe specific surface immunofluorescence in infected L-929 or mastocytoma P-81 5-X2 cells, beginning $2 \mathrm{~h}$ after infection, using human anti-vaccinia hyperimmune sera. Fluorescence was more pronounced and visible on a higher percentage of cells in later stages of infection, reaching a percentage of $70-80 \%$ of labeled cells.

\subsection{Effects of sensitized lymphocytes on infected target cells}

$\mathrm{C} 3 \mathrm{H} / \mathrm{TIF}$ mice were infected intraperitoneally with $2 \mathrm{ml}$ Eagle's medium containing $10^{6} \mathrm{TCID}_{50} / \mathrm{ml}$ vaccinia virus. Control animals received virus-free medium. Six days later the mice were sacrificed, the spleens of 5 mice from each group were pooled and spleen cell suspensions were prepared. The cells were incubated for $20 \mathrm{~h}$ with ${ }^{51} \mathrm{Cr}$-labeled, infected and noninfected L-929 cells and the ${ }^{51} \mathrm{Cr}$ release was calculated. Incubation of spleen cells from sensitized mice with vaccinia virusinfected target cells led to significant chromium release, while noninfected targets remained unaffected. Control spleen cells did not relevantly affect the target cells (Table 1 ).

Table 1. Cytotoxic effect ${ }^{\mathrm{a})}$ of $\mathrm{C} 3 \mathrm{H}$ lymphocytes against vaccinia virus-infected $\mathrm{L}-929$ cells

\begin{tabular}{|c|c|c|}
\hline \multirow[b]{2}{*}{ Lymphocytes $^{b)}$} & \multicolumn{2}{|c|}{ Target cells } \\
\hline & Infectedc) & Noninfected \\
\hline $\begin{array}{l}\text { Vaccinia virus } \\
\text { infected spleen }\end{array}$ & $82.4 \pm 3.4^{d)}$ & $36.6 \pm 0.3$ \\
\hline Normal spleen & $28.2 \pm 2.4$ & $30.0 \pm 1.7$ \\
\hline Nil & $24.5 \pm 0.7$ & $17.5 \pm 0.8$ \\
\hline
\end{tabular}

a) Mean $\%{ }^{51} \mathrm{Cr}$ release \pm standard error of the mean from groups of 5 wells.

b) Lymphocytes from a pool of 4-6 mice, purified by Ficoll-Isopaque gradient centrifugation. Mice were injected 6 days previously with $1 \mathrm{ml} 1 \times 106 \mathrm{TCID}_{50} / \mathrm{ml}$ vaccinia virus i.p. Ratio lymphocytes: targets $=100: 1$.

c) $5 \times 10^{4}$ L-929 cells/well infected $12 \mathrm{~h}$ previously with $5 \times 10^{5}$ $\operatorname{TCID}_{50} / 0.2 \mathrm{ml}$ of vaccinia virus for $2 \mathrm{~h}$ at $37^{\circ} \mathrm{C}$, then incubated in complete medium.

d) Significantly greater ${ }^{51} \mathrm{Cr}$ release from virus-infected L-929 cells by immune lymphocytes compared to normal lymphocytes $(\mathrm{P}<0.001)$; significantly greater ${ }^{51} \mathrm{Cr}$ release by immune lymphocytes from infected L-929 cells compared to noninfected L-929 cells $(\mathrm{P}<0.001)$.

\subsection{Virus specificity of infected target cell lysis}

C3H mice were injected with $1 \times 10^{7}$ viable $\mathrm{BCG}$ organisms (Behring-Werke, Marburg), $1 \mathrm{ml}$ MEM containing $1 \times 10^{6}$ $\mathrm{TCID}_{50} / \mathrm{ml}$ herpes simplex virus type $\mathrm{I}, 1 \mathrm{ml}$ MEM containing $1 \times 10^{6} \mathrm{TClD}_{50} / \mathrm{ml}$ vaccinia virus or Eagle's medium alone. The spleen cells were harvested 6 days later and incubated for $20 \mathrm{~h}$ with either vaccinia virus-infected or noninfected L-929 cells. Only cells from vaccinia virus-sensitized animals were able to lyse the infected target cells in significant amounts (Table 2).

\subsection{Time course of development of cytotoxic lymphocytes}

$\mathrm{C} 3 \mathrm{H}$ mice were injected with $2 \mathrm{ml}$ containing $1 \times 10^{5.4} \mathrm{TCID}_{50} /$ $\mathrm{ml}$ vaccinia virus. Beginning 2 days after injection, groups of 5 infected or mock-infected animals were killed and the cytotoxicity test was performed. Occurrence of CL could be observed after 2 days, reaching a maximum after one week and declining in the second week after infection (Fig. 1). At day 12 only weak cytotoxicity remained. 
Table 2. Specificity of vaccinia virus-infected target cell lysis

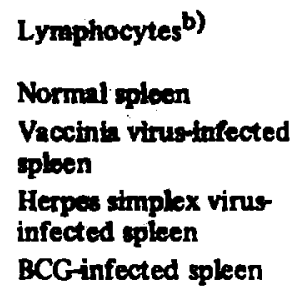

Infected L-929 cells

$6.0 \pm 1.7$

$58.2 \pm 1.2^{c)}$

$5.0 \pm 2.0$

$12.5 \pm 3.1$

a) Mean $\%{ }^{51} \mathrm{Cr}$ release $\pm \mathrm{SEM}, 5$ wells per group.

b) Lymphocytes from a pool of 6 mice/group. Mice were injected intraperitoneally 6 days previously with $1 \mathrm{ml} 1 \times 10^{6} \mathrm{TCID}_{50} / \mathrm{ml}$ vaccinia virus, $1 \mathrm{ml} 1 \times 10^{6} \mathrm{TCID}_{50} / \mathrm{ml}$ herpes simplex virus type 1 or $1 \mathrm{ml}$ containing $10^{7}$ viable BCG orga nisms. Ratio lymphocytes: infected target cells $=100: 1$.

c) Significant ${ }^{51} \mathrm{Cr}$ release $(\mathrm{P}<0.001)$. No significant ${ }^{51} \mathrm{Cr}$ release in the other groups.

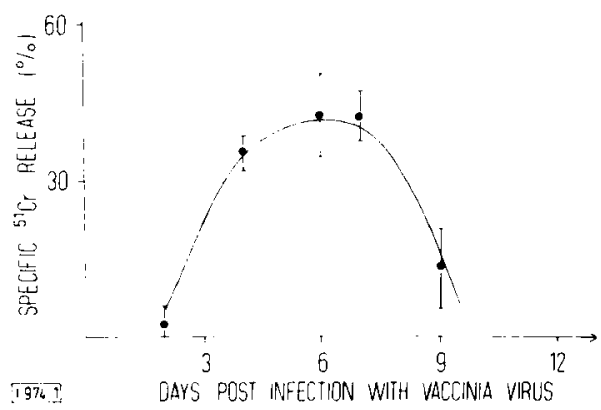

Figure 1. Time dependence on the appearance of cytotoxic effector cells in vivo. Percent specific ${ }^{51} \mathrm{Cr}$ release from mouse spleen cells harvested at different intervals after intraperitoneal injection of $2 \mathrm{ml}$ $10^{5.4} \mathrm{TCID}_{50} / \mathrm{ml}$ vaccinia virus. Release of normal spleen cells was subtracted. Each point represents the mean of 5 wells \pm 2 SEM, lymphocyte: target cell ratio $=100: 1$.

\subsection{In vitro kinetics of target cell lysis}

The following experiment was performed using a constant ratio (100:1) of lymphocytes to target cells. Spleen lymphocytes were obtained from 6-day infected $\mathrm{C} 3 \mathrm{H}$ mice and control animals. While the total amount of lymphocytes was kept constant, different percentages of lymphocytes from sensitized animals were mixed with normal lymphocytes and incubated with the target cells. At intervals of $5 \mathrm{~h}$ the reactions were stopped and the ${ }^{51} \mathrm{Cr}$ release was tested. Specific lysis could be observed as early as at $5 \mathrm{~h}$ incubation. The increase of ${ }^{51} \mathrm{Cr}$ release takes a nearly linear course when correlated with time. The time-dependent increase of ${ }^{51} \mathrm{Cr}$ release is consistent with the percentage of sensitized lymphocytes in the reaction (Fig. 2).

The ratio of 100 lymphocytes to 1 target cell seems to be the optimal concentration of effector cells to targets. Further additions of sensitized lymphocytes to a constant number of target cells exceeding the ratio 100:1 do not lead to an increase of chromium release (Fig. 3 ). In some experiments a slight decrease of ${ }^{51} \mathrm{Cr}$ release could be observed at ratios over 100:1.

\subsection{Effect of anti-vaccinia antibodies on vaccinia virus- infected target cell lysis}

Incubation of infected target cells with human anti-vaccinia antibody together with agarose-absorbed guinea pig complement for $20 \mathrm{~h}$ resulted in only slight cytolysis. Antibody or

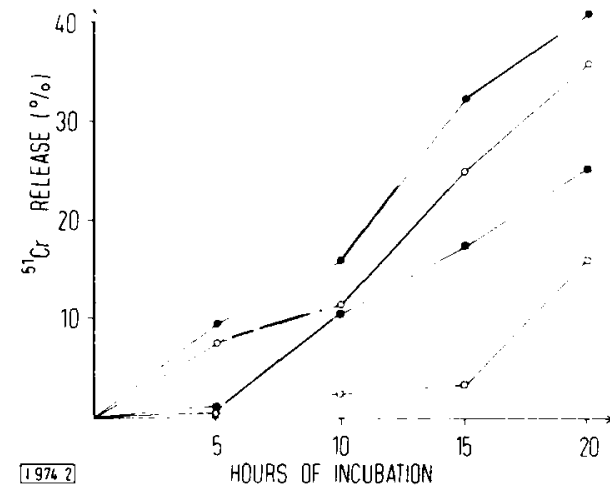

Figure 2. Kinetics of target cell lysis in vitro. Number of target celis (L-929, vaccinia infected): $5 \times 10^{4} /$ well. Number of lymphocytes: $5 \times 10^{6} /$ well. Mixtures of normal lymphocytes with lymphocytes from mice immunized 6 days previously; $\% 51 \mathrm{Cr}$ release was measured at intervals of $5 \mathrm{~h}$. Each point represents the mean of 5 wells. Percentage of immune lymphocytes: $(\square-\square) 25,(\bullet-\bullet) 50,(\circ-)$ 75 , and $(\bullet-\bullet) 100$

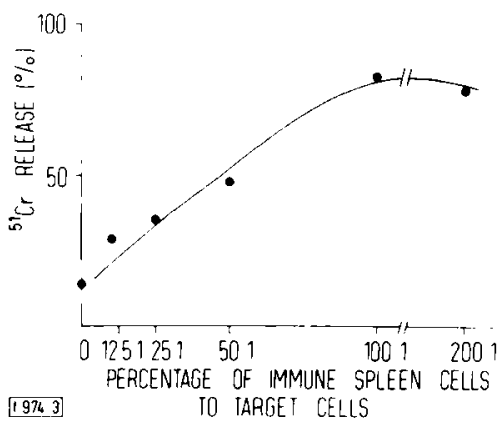

Figure $3 .{ }^{51} \mathrm{Cr}$ release with different lymphocytes to target cell ratios. Increasing numbers of lymphocytes from 6 day immunized mice were incubated with a constant number $\left(5 \times 10^{4}\right)$ of va ccinia virusinfected L-929 cells. Each point represent $s$ the mean of 5 wells.

complement alone had no cytotoxic effect. The incubation of infected target cells, specific antibodies and sensitized lymphocytes together for $20 \mathrm{~h}$ led to a significant reduction of ${ }^{51} \mathrm{Cr}$ release. This blocking effect of antiserum could also be obtained using rabbit hyperimmune serum or syngeneic hyperimmune serum from $\mathrm{C} 3 \mathrm{H}$ mice. Normal serum had no blocking activities (Table 3 ).

\subsection{Characterization of the effector cell}

In the in vitro system virus-specific cytolysis of vaccinia-infected target cells could be obtained with spleen cells and peritoneal exudate cells from vaccinia virus-infected animals, while normal cells had no effect. Immune spleen lymphocytes were incubated with anti-mouse $\mathrm{lg}$ for $30 \mathrm{~min}$, washed and reincubated with absorbed guinea pig complement. This procedure led to a $46 \%$ killing of Ficoll-Isopaque purified cells. Spleen cell cytotoxicity was not found to be reduced significantly. Likewise the elimination of Ig-bearing cells by adherent properties in a nylon wool column had no effect on the cytolytic activity of the effluent cell fraction.

A glass bead column was used to eliminate macrophages. The removal of macrophages had no effect on target cell lysis. These results suggest that cells with adherent properties. including macrophages and B cells, and equally Ig-bearing cells such as B cells and other cells with surface adsorbed immunoglobulins, for example macrophages coated with 
Table 3. Effect of anti-vaccinia antibodies on lymphocyte-mediated lysisa) of vaccinia virus-infected L-929 target cells

\begin{tabular}{|c|c|c|c|}
\hline Exp. & Lymphocytes & Serum & $\begin{array}{c}{ }^{51} \mathrm{Cr} \text { relcase } \\
(\pi)\end{array}$ \\
\hline \multirow[t]{2}{*}{1} & Immune spicen & $\begin{array}{l}\text { Normal mouse } \\
\text { Vaccinia immune } \\
\text { mouse }\end{array}$ & $\begin{array}{l}77.0 \pm 1.3 \\
35.0 \pm 1.6 \mathrm{~d})\end{array}$ \\
\hline & Immune spleen & $\begin{array}{l}\text { Normal rabbit } \\
\text { Vaccinia immuneb) } \\
\text { rabbit }\end{array}$ & $\begin{array}{l}66.5 \pm 0.9 \\
34.5 \pm 1.0 \mathrm{~d})\end{array}$ \\
\hline \multirow[t]{3}{*}{2} & Immune spleen & $\begin{array}{l}\text { Normal human } \\
\text { Vaccinia immunes) } \\
\text { human }\end{array}$ & $\begin{array}{l}77.3 \pm 0.8 \\
\left.27.3 \pm 1.4^{d}\right)\end{array}$ \\
\hline & Normal spleen & $\begin{array}{l}\text { Normal human } \\
\text { Vaccinia immune } \\
\text { human }\end{array}$ & $\begin{array}{l}31.0 \pm 1.1 \\
26.3 \pm 1.2\end{array}$ \\
\hline & & $\begin{array}{l}\text { Vaccinia immune } \\
\text { human + guinea pig } \\
\text { complement }\end{array}$ & $30.6 \pm 1.8$ \\
\hline
\end{tabular}

a) Lymphocytes from 6-day previously infected mice. Ratio lymphocytes: target cells $100: 1$, mean $\%{ }^{51} \mathrm{Cr}$ release \pm SEM, 3 wells per group:

b) Serum obtained after 3 injections of $1 \mathrm{ml} 1 \times 10^{6} \mathrm{TCID}_{50} / \mathrm{ml}$ or $5 \mathrm{ml} 1 \times 10^{6} \mathrm{TCID}_{50} / \mathrm{ml}$ (rabbit) vaccinia virus.

c) Hyperimmunglobulin (Vacciniabulin, Immuno ${ }^{R}$ ) 48 h dialyzed against phosphate buffered saline, then diluted 1:5 in MEM.

d) Significant inhibition of ${ }^{51} \mathrm{Cr}$ release by immune mouse $(\mathrm{P}<0.001)$, rabbit $(P<0.001)$ and human $(P<0.001)$ sera.

cytophilic antibodies, are not responsible for vaccinia virusspecific target cell killing.

After incubation of cells with anti- $\Theta$ serum and then with complement, $32 \%$ of cells were dead, calculated by trypan blue exclusion. The treatment of spleen cell or peritoneal exudate cells with anti- $\Theta$ serum and complement resulted in significant reduction of target cell killing. Treatment with anti- $\Theta$ serum without complement is not followed by reduction of ${ }^{51}$ Cr release (Table 4 ).

Table 4. Classification of the cytotoxic lymphocyte

\section{Treat ment of immune lymphocytes ${ }^{b)}$}

$\begin{array}{ll}\text { lintreated } & 52.0 \pm 0.8 \\ \begin{array}{l}\text { Nylon wool column } \\ \text { adsorption }\end{array} & 53.0 \pm 2.0 \\ \begin{array}{l}\text { Glass bead column } \\ \text { adsorption }\end{array} & 48.9 \pm 1.6 \\ \text { Anti-mouse Ig }+ \text { C } & 41.6 \pm 1.2 \\ \text { Anti- } \Theta \text { serum }+ \text { C } & 17.2 \pm 2.3 \mathrm{C}) \\ \text { Anti- }- \text { serum without C } & 45.5 \pm 0.9\end{array}$

a) Mean $\%{ }^{51} \mathrm{Cr}$ release, SEM from groups of 5 wells.

b) Lymphocyte from 6-day infected mice, lymphocyte: target cell ratio $=50: 1$.

c) Significant reduction $(P<0.001)$ of target cell lysis after pretreatment of lymphocytes with anti- $\Theta$ serum and complement.

\subsection{Effect of target cell specificity on virus-specific lympho- cyte cy totoxicity}

Sensitized lymphocytes from $\mathrm{C} 3 \mathrm{H}$ mice were able to kill vaccinia-infected L-929 cells; the noninfected cells usually were not affected. When lymphocytes from DBA/2 mice were used, the vaccinia-infected L-929 cells were not killed by the normal or the immune lymphocytes. Likewise the immune lymphocytes from $\mathrm{C} 3 \mathrm{H}$ mice no longer had cytolytic activities on vaccinia-infected mastocytoma P-81 5-X2 target cells. Immune cells from $\mathrm{C} 57 \mathrm{BL} / 6 \mathrm{~J}$ mice had no significant effects on vaccinia infected $L-929$ cells or vaccinia-infected mastocytoma P-815-X2 cells (unpublished data). When a cross-reaction was performed using cells from normal and infected $\mathrm{C} 3 \mathrm{H}$ and DBA/2 mice against infected and noninfected L-929 and mastocytoma $\mathrm{P}-81$ 5-X2 target cells. $\mathrm{C} 3 \mathrm{H}$ lymphocytes only lysed infected L-929 cells, while DBA/2 lymphocytes only lysed the infected mastocy toma P-81 5-X2 cells (Table 5).

Since $\mathrm{C} 3 \mathrm{H}$ mice and $\mathbf{L}-929$ cells share the same $\mathbf{H}-2^{\mathbf{k}}$ antigen and DBA $/ 2$ mice have the same $\mathrm{H}-2^{\mathrm{d}}$ antigen as do mastocytoma P-815-X2 cells, it could be concluded that vaccinia virus-specific lymphocyte cytotoxicity for target cells is dependent on transplantation antigen compatibilities.

Table 5. Percent ${ }^{51} \mathrm{Cr}$ release ${ }^{a)}$ from vaccinia virus-infected and noninfected target cells by $\mathrm{CL}$ from normal and vaccinia virus-infected miceb)

\begin{tabular}{|c|c|c|c|c|}
\hline $\begin{array}{c}\text { Splcen } \\
\text { lymphocytes }\end{array}$ & Infected & $\begin{array}{r}\text { Noninfect } \\
{ }^{1} \mathrm{C}\end{array}$ & $\begin{array}{l}\text { Mastocytom } \\
\text { Infected } \\
\text { elease }(\%)\end{array}$ & $\begin{array}{l}\text { P-815-X2 } \\
\text { Noninfecte }\end{array}$ \\
\hline None & $24.7 \pm 1.1$ & $13.1 \pm 2.3$ & $24.1 \pm 1.3$ & $21.0 \pm 1.6$ \\
\hline $\begin{array}{l}\text { C3H (H-2k) } \\
\text { immune } \\
\text { normal }\end{array}$ & $\begin{array}{l}\left.77.0 \pm 1.2^{c}\right) \\
28.3 \pm 2.7\end{array}$ & $\begin{array}{l}33.5 \pm 0.9 \\
30.8 \pm 0.7\end{array}$ & $\begin{array}{l}13.0 \pm 1.5 \\
10.4 \pm 1.2\end{array}$ & $\begin{array}{l}5.6 \pm 0.4 \\
1.8 \pm 0.4\end{array}$ \\
\hline $\begin{array}{l}\text { DBA/2 (H-2C } \\
\text { immune } \\
\text { normal }\end{array}$ & $\begin{array}{l}\text { d) } \\
19.2 \pm 2.8 \\
16.0 \pm 3.2\end{array}$ & $\begin{array}{l}32.2 \pm 1.8 \\
20.2 \pm 3.1\end{array}$ & $\begin{array}{l}60.6 \pm 1.6 c) \\
12.4 \pm 1.0\end{array}$ & $\begin{array}{l}2.0 \pm 0.3 \\
2.4 \pm 0.5\end{array}$ \\
\hline
\end{tabular}

a) Mean of 5 wells \pm SEM in each group.

b) Mice were injected intraperitoneally 6 days previously with $1 \mathrm{ml}$ $10^{6} \mathrm{TCID} 50 / \mathrm{ml}$ of vaccinia virus.

c) Significantly greater ${ }^{51} \mathrm{Cr}$ release $(\mathrm{P}<0.001)$ of immune lymphocytes against syngeneic infected target cells compared to the action of normal cells, or to the action of immune lymphocytes against allogeneic infected and noninfected target cells.

\section{Discussion}

Most systems in which specific killing of virus-infected target cells by immune lymphocytes has been described, work with viruses which themselves have no or only slight cytolytic effects on the target cells. Recently, virus-specific cy totoxicity could also be demonstrated in an acute virus infection which leads to virus-induced target cell destruction [14]. Vaccinia virus infection eventually results in target cell destruction, so that the incubation time for the in vitro experiment is limited. In spite of this restriction it is a good model to study the in vitro actions of immune effector cells.

The time course of development of $\mathrm{CL}$ in our experiments was similar to other experimental systems investigating cytotoxic effects on cells infected with different viruses $[12,15]$. One can suggest that the appearance and disappearance of cytotoxic lymphocytes take a regular course, but there is no information as to what happens to this effector cell population after the decrease of cytotoxicity two weeks after infection. It is not clear if these cells are identical to those that show antigen-specific blast transformation and release of factors. The appearance of lymphocytes which develop specific blast transformation to vaccinia virus seems to be delayed com- 
pared with the appearance of cytotoxic cells. In transformation experiments with lymphocytes from vaccinated persons no booster effect in blast transformation after revaccination could be observed [23], while there was an increase of interferon production [24]. Experiments are under study investigating the possibility of reactivating cytotoxic lymphocytes in vivo after reinfection.

The kinetic studies show that the rate of target cell lysis is augmented constantly with time and with increasing numbers of CL. The results represented here are virus-specific; $C L$ from animals infected with herpes simplex virus type I or viable BCG organisms have no effect on vaccinia virusinfected target cells. A second argument for virus specificity is the blocking effect of anti-vaccinia antibody. Blocking could be achieved with antibodies from different species. It was not possible to show a blocking effect when the ectromelia virus was used in the same system. The possibility of recognizing antigens of different complexity by $B$ and $T$ cells [25], competition of $T$ cells and antibodies for the receptor or merely insufficient concentration of antibodies were discussed. We suggest that inadequate concentrations of antibodies may have led to negative results, since dilution of antibody to $1: 25$ resulted in only minimal inhibition. On the other hand one has to take into account that antibodies which are capable of neutralizing the infective virus may differ in their activity against virus-specific surface antigens.

It has been demonstrated that antibodies can be raised which are directed only against virus-specific surface antigens or viral structural antigens of vaccinia virus [26]. It has, however, to be elucidated if antibodies, which are directed solely against viral structural antigens, are able to block the action of CL.

The studies with purified $T$ cells after the elimination of $B$ cells and macrophages using adherent properties, as well as the effects of anti-Ig antibodies and anti- $\Theta$ serum, lead to the suggestion that the $T$ cell alone is the effector cell which is able to lyse the infected target cell, in the absence of B cells, antibodies, complement or other soluble factors. The results are consistent with the findings of other investigations in which the cell type of CL against virus-infected cells [13, 14,27 ] or cells differing by transplantation antigens or tumorassociated transplantation antigens could be characterized as a $T$ cell $[28,29]$.

It seems obvious that $\mathrm{CL}$ play a role in host resistance to viral infections, but the importance of this effect remains to be defined. It has been shown recently that in an acute infection with sindbis virus, CL have no effect on virus clearance [14]. Virus clearance could be attributed to the action of macrophages which may act in an activated state or be "armed" by immune T cells [30] with or without the help of antibodies or lymphocytes [31]. In the vaccinia system we could show that clearance of virus in vitro is possible without the cytolysis by $\mathrm{CL}$ (manuscript in preparation).

In our experimental system $\mathrm{CL}$ from $\mathrm{C} 3 \mathrm{H}$ mice could only kill infected $\mathrm{L}$ cells but not infected or noninfected mastocytoma P815-X2 cells. The action of CL from DBA/2 mice was also specific; they had cytolytic effects only on infected mastocytoma cells. In a recent investigation it has been observed [15] that in the lymphocytic choriomeningit is system, target cell lysis was restricted to syngeneic or semiallogeneic systems. Since LCM is a budding virus it seems possible that this effect was caused by this type of virus maturation, followed by alteration of $\mathrm{H}-2$ antigen concentration on the sur- face of infected cells [32]. The $\mathrm{H}-2$ antigen-specific restriction of cytolysis in the vaccinia system suggests that this restriction is caused by a more general phenomenon. This is supported by the data of Shearer [33], showing cell-mediated cytotoxicity to trinitrophenyl-modified lymphocytes in a syngeneic system. In another pox virus system using ectromelia virus, different $C L$ activities on various-infected cells were interpreted as different expressions of viral surface ant $\mathrm{i}$. gens on the target cells [13]. However, if one correlates the results of specific target cell destruction with $\mathrm{H}-2$ antigen compatibility, there is a decrease of cytolytic effects consistent with increasing antigenic heterogenicity. Secondly, the infected mastocytoma cell was, in our system, just as lysable as the $\mathbf{L}$ cells under the prerequisite that the syngeneic cytolytic effector cell was used. Other investigators communicated virus-specific lysis of heterologous infected target cells $[5,10,11]$. For these systems the T cell specificity of the reaction has to be elucidated to exclude antibody-dependent activities [34-37]. On the other hand, one could also suppose that high concentrations of virus-specific antigens on cell surfaces can be recognized in spite of foreign transplantation antigen structures.

The authors gratefully acknowledge the accurate technical assistance of Ms. K.B. Henderson.

Received December 3, 1974.

\section{References}

1 Von Pirquet, C.E., Arch. Intern. Med. 1911. 7: 259.

2 Glasgow, L.A., Arch. Intern. Med. 1970. 126: 125.

3 Good, R.A. and Varco, R.L., Lancet 1955. 75: 245.

4 Fulginiti, V.A., in Kagan, B.M. and Stielum, E.R. (Eds.), Immunologic Incompetence, Yearbook Publ., Chicago 1971, p. 245.

5 Speel, L.F., Osborn, J.E. and Walker, D.L., J. Immunol. 1968. 101: 409.

6 Lundstedt, C., Acta Pathol. Microbiol. Scand. 1969. 75: 139.

7 Oldstone, M.B. and Dixon, F.I., Virology 1970. 42: 805.

8 Marker, O. and Volkert, M., J. Exp. Med. 1973. 137: 151.

9 Profitt, M.R., Hirsch, M.S. and Black, P.H., J. Immunol. 1973. 110: 1183 .

10 Steele, R.W., Hensen, S.A., Vincent, M.M., Fucillo, D.A. and Bellanti, J.A., J. Immunol. 1973. 110: 1502.

11 Labowskie, R.A., Edelman, R., Rustigian, R. and Bellanti, J.A., J. Infec. Dis. 1974. 129: 233.

12 Gardner, I., Bowern, N.A. and Blanden, R.V., Eur. J. Immunol. 1974. 4: 63.

13 Gardner, I., Bowern, N.A. and Blanden, R.V., Eur. J. Immunol. 1974. 4:68.

14 McFarland, H.F., J. Immunol. 1974. 113: 173.

15 Zinkernagel, R.M. and Doherty, P.C., Nature 1974. 248: 701.

16 Boyum, A., Scand. Clin. Lab. Invest. 1968. Suppl 21. 97: 77.

17 Shortman, K., Williams, N., Jackson, H., Russell, P., Byrt, P. and Diener, E., J. Cell. Biol. 1971. 48: 566.

18 Julius, M.H., Simpson, E. and Herzenberg, L.A., Eur. J. Immunol. 1973. 3: 645

19 Janossy, G. and Greaves, M.F., Clin. Exp. Immunol. 1971. 9: 483.

20 Cohen, A. and Schlesinger, M., Transplantation 1970. 10:130.

21 Brunner, K.T., Mauel, J., Cerottini, J.-C. and Chapuis, B., J. Immunol. 1968. 14: 181.

22 Ueda, Y., Tagaya, I., Amano, H. and Ho, M., Virology 1972. 49: 794.

23 Koszinowski, U., Volkmann, B. and Thomssen, R., Z. Immunitätsforsch. Exp. Ther. 1975, in press. 
24 Epstein, L.B., Stevens, D.S. and Merigan, T.C., Proc. Nat. Acad. Sci. US 1972. 69: 2632.

25 Alkan, S.S., Williams, E.B., Nitecki, D.E. and Goodman, J.E., J. Exp. Med. 1972. 135: 1228.

26 Ueda, Y. and Tagaya, I., J. Exp. Med. 1973. 138: 1033.

27 Zinkernagel, R.M. and Doherty, P.C., J. Exp. Med. 1973. 138: 1266.

28 Wagner, H. and Röllinghoff, M., J. Exp. Med. 1973. $138: 1$.

29 Wagner, H., J. Exp. Med. 1973. 138: 1379.

30 Evans, R. and Alexander, P., Nature 1972. 236: 168.
31 Lohmann-Mathes, M.-L., Schipper, H. and Fischer, H., Eur. J. Immunol. 1972. 2: 45.

32 Hecht, T.T. and Summers, D.F., J. Virol. 1972. 10: 578.

33 Shearer, G.M., Eur. J. Immunol. 1974. 4: 527.

34 Perlmann, P. and Perlmann, H., Cell. Immunol. 1970. 1: 300.

35 Perlmann, P., Perlmann, H. and Wigzell, H., Transplant. Rev. 1972. 13: 91.

36 Calder, E.A., Penhale, W.J., Barnes, E.W. and Irvine, W.J., Clin. Exp. Immunol. 1973. 14: 19.

37 Schirrmacher, V., Rubin, B., Pross, H. and Wigzell, H., J. Exp. Med. 1974. 139: 93.

\section{H.R. MacDonald ${ }^{+}$}

Department of Immunology, Swiss Institute for Experimental Cancer Research, Lausanne

\section{Early detection of potentially lethal events in T cell- mediated cytolysis*}

\begin{abstract}
The short-term kinetics of the interaction between mouse cytolytic $\mathrm{T}$ lymphocytes (CTL) and ${ }^{51} \mathrm{Cr}$-labeled target cells was investigated. It was found that addition of EDTA to mixtures of CTL and target cells instantaneously blocked de novo lytic interactions, but did not inhibit the release of ${ }^{51} \mathrm{Cr}$ from already damaged target cells. Using this information, a modified cytolytic assay was developed. By applying this assay to highly active CTL populations generated in secondary mixed leukocyte cultures, it was possible to detect appreciable target cell damage as early as 30 seconds after exposure to CTL. Quantitative studies demonstrated linear relationships between cytolysis and time and between rate of cytolysis and cell number under these assay conditions.
\end{abstract}

\section{Introduction}

The specific in vitro destruction of ${ }^{51} \mathrm{Cr}$-labeled target cells by cytolytic thymus-derived lymphocytes (CTL) is a wellcharacterized model system in which to study the efferent phase of cell-mediated immunity [1]. At the present time, however, studies of the mechanism of CTL-mediated cytolysis at the molecular level are restricted by the relatively long duration ( $3-18 \mathrm{~h}$ ) of commonly used assay systems. In order to circumvent this problem, we have modified the cytolytic assay so as to restrict the interaction between CTL and target cells to very short time periods. The rationale for this modification is based on the earlier observation that the addition of ethylenediaminetetraacetic acid (EDTA) to mixtures of CTL and target cells resulted in complete inhibition of ${ }^{51} \mathrm{Cr}$ release if EDTA was added at the beginning of the assay period, but only partial inhibition when added at later times $[2,3]$. In view of the recent demonstration that ${ }^{51} \mathrm{Cr}$ release may continue for several hours following inactivation of CTL by antibody and complement [4] or by heating to $45^{\circ} \mathrm{C}[5]$, a likely interpretation of the earlier results is that

[I 987]

* This work was supported by grants from the Swiss National Foundation for Scientific Research.

+ Supported by a Postdoctoral Fellowship from the Medical Research Council of Canada.

Correspondence: H. Robson MacDonald, Radiobiology Section, Ontario Cancer Foundation, Victoria Hospital, London, Ontario N6A4G5, Canada

Abbreviations: CTL: Cytolytic thymus-derived lymphocytes MLC: Mixed leukocyte culture MLC-Imm: Secondary mixed leukocyte culture
EDTA prevents the de novo initiation of target cell damage, but has no effect on the release of ${ }^{51} \mathrm{Cr}$ from already damaged target cells.

In the present study, the minimal duration of cell contact necessary to initiate lethal target cell damage has been estimated by making use of this property of EDTA. In particular, by applying this analysis to highly active CTL populations generated in secondary mixed leukocyte cultures (MLC-Imm) [6], we have been able to detect appreciable target cell damage as early as $30 \mathrm{sec}$ after exposure to CTL at appropriate temperatures. Furthermore, the rate of target cell damage has been found to proceed linearly with time under these experimental conditions. The significance of these findings for the utilization and interpretation of ${ }^{51} \mathrm{Cr}$ release assays will be discussed.

\section{Materials and methods}

\subsection{Mice}

Adult female mice of the inbred strains $\mathrm{C} 57 \mathrm{BL} / 6$ and $\mathrm{DBA} / 2$ were supplied by the animal colony maintained at the Swiss Institute for Experimental Cancer Research, Lausanne, Switzerland. Original breeding pairs were obtained from the Jackson Laboratories, Bar Harbor, Maine.

\subsection{Generation of effector cells}

Cytoly tic thymus-derived lymphocytes (CTL) were generated in mixed leukocyte cultures (MLC) using C57BL/6 spleen cells as responding cells and irradiated (1000 rads) DBA/2 spleen cells as stimulating cells. A detailed description of the culture conditions has been published elsewhere [6]. In some 